\title{
Evaluation of Heavy Metals in Cassava Tubers Grown around Two Major Cement Factories in Ogun State, Nigeria
}

\author{
Makanjuola, Olakunle Moses \\ Department of Food Technology, Federal Polytechnic, Ilaro, Ogun State,Nigeria
}

\begin{abstract}
Unlike organic wastes, heavy metals are non-biodegradable and can be accumulated in living tissues, causing various diseases and disorders. The cement plants found in strategic areas of human habitat consistently emit toxic dust and gases over large areas through wind and rain which are largely accumulated in soils, plants and river bodies. This research study investigates the presence of heavy metals in cassava tubers grown around two major cement factories in Ogun state, south west, Nigeria. The findings revealed the presence of heavy metals like lead, calcium, zinc, copper, iron, arsenic, aluminum, potassium, manganese and chromium in their vary levels of toxicity, well above the stipulated limits set by food and agricultural organization and world health organization, hence the inhabitants where these cement facilities are located are vulnerable to health related diseases associated with heavy metals.
\end{abstract}

Keywords: Evaluation, heavy metals, cassava tubers, cement factories.

\section{INTRODUCTION}

Heavy metal is a general collective term, which applies to the group of metals and metalloids with atomic density greater than $4 \mathrm{~g} / \mathrm{cm}^{3}$ or 5times greater than water [1]. Heavy metals, have been excessively released into the environment due to rapid industrialization and have created a major global concern. The metals have important positive and negative roles in human life [2,3,4,5].

Unlike organic wastes, heavy metals are non-biodegradable and can be accumulated in living tissues, causing various diseases and disorders. Metals such as cadmium and copper are cumulative poisons, which cause environmental hazards and are reported to be exceptionally toxic [6]. Accumulation of heavy metals in crop plants is often of great concern due to its potential for food contamination through the soil root interface [7].

Cassava is the third largest source of food carbohydrate in the tropics, after rice and maize. Cassava is a major staple food in the developing world, providing a basic diet for over a half a billion people. Nigeria currently produces about 54 million metric tonnes (MT) per annum [8], making her the highest cassava producer in the world, producing more than Brazil and almost double the production capacity of Thailand and Indonesia. Cassava is a hardy crop, tolerant to extreme ecological conditions and even thrives on impoverished soils. The roots are $25.35 \%$ starchy and the leaves contain significant amounts of protein and other nutrients. Common products from edible portion of the cassava tubers especially garri, fufu and cassava starch are widely consumed by the local population and constitutes one of the major ingredients in the local staple [9].

The environmental concern in cement manufacture is primarily related to the emission of dust and gases [10]. Cement dust can spread over large areas through wind and rain and are accumulated in and on soils, plants, and have the potential to affect animal and human health adversely [11].The problem of air pollution in the form of particulates has become a threat to the survival of plants and the reduction of the integrity of soils in the industrial areas [12].

Excessive accumulation of heavy metals in agricultural soils, resulting in elevated heavy metal. Uptake by food crops is of great concern because of potential health risk to the local inhabitants [13]. Therefore, this present work is undertaken to establish the presence of heavy metals as well as evaluating their levels in cassava roots grown around two major cement manufacturing companies in Ogun state, Nigeria and compare their levels to standards as stipulated by relevant standard bodies such as WHO/FAO [2013]. 


\section{Materials ANd Methods}

Study areas: The study areas are located in Ibega, via Ilaro, about $120 \mathrm{~km}$ from Lagos and Ewekoro at km 64, Lagos/Abeokuta expressway, Ewekoro in Ogun state, south-west Nigeria. The two cement factories i.e Dangote and Larfarge, both located in Ogun state plays a significant role in the local building industry and in the economy of Nigeria. Both cement factories surrounding areas are essentially rural with minor agricultural activities.

Source of materials: Matured fresh cassava tubers were harvested from several locations around these cements factories. The samples were collected in sacks, labeled according to location and transported to the laboratories of food technology department of the federal polytechnic Ilaro for analysis. All reagents and chemicals used for the analysis were of analytical grade. All the glass wares were thoroughly washed, rinsed with deionized water before use.

\section{SAMPle Preparation}

The cassava tubers were thoroughly washed with clean portable water to remove dirts, insect fragments, surface acids etc. They were then peeled to remove their coats and the cuticles, were then removed with stainless steel knife, and the edible parts were cut into pieces of about $10 \mathrm{~cm}^{3}$ to increase their surface areas for easy drying. They were then placed on aluminum trays and dried in electric ovens at $105^{\circ} \mathrm{c}$ to a constant weight. The dried samples were pulverized with mortal and pestle and kept in desiccators prior to digestion.

\section{Analytical Procedure for Heavy Metals}

Digestions of samples were carried out using methods of Adedeji and Ajibode (2005). $1 \mathrm{~g}$ of cassava samples was weighed into a $50 \mathrm{ml}$ digestion tube and $1 \mathrm{ml}$ of hydrogen peroxide $\left(\mathrm{H}_{2} \mathrm{O}_{2}\right)$ solution, $2 \mathrm{ml}$ of concentrated hydrochloric acid (HCL), $5 \mathrm{ml}$ of concentrated Nitric acid $\left(\mathrm{HNO}_{3}\right)$, Hypochlorate $(1: 1)$ and $2 \mathrm{ml}$ of concentrated sulphuric acid $\left(\mathrm{H}_{2} \mathrm{SO}_{4}\right)$ were added. The content was heated at $105^{\circ} \mathrm{c}$ till the solution became clear. The sample was then coded and filtered into a standard volumetric flask. A blank digestion was carried out for comparisons. Standard solution for each element was then prepared and was used for the calibrations. Metal measurement was performed using Atomic Absorption Spectrophotometer (AAS) (pye Unicom SP 2900 model).

Determinations were carried out in triplicates

\section{Statistical Analysis}

Statistical analysis of data obtained was carried out using the statistical package for social science (SPSS). Analysis of variance (ANOVA) was used to separate the means.

Table1. Result of Analysis showing heavy metal concentrations in cassava tubers grown around Dangote and Larfarge cement factories in Ogun state, Nigeria.

\begin{tabular}{|l|l|l|}
\hline Parameters $\mathbf{( M g / K g ) ~}$ & Dangote Cement Factory & Larfarge Cement Factory \\
\hline Lead & $0.09 \pm 0.06$ & $0.28 \pm 0.03$ \\
\hline Copper & $4.75 \pm 0.02$ & $7.60 \pm 0.17$ \\
\hline Arsenic & $0.32 \pm 0.03$ & $0.36 \pm 0.01$ \\
\hline Zinc & $4.03 \pm 0.21$ & $5.00 \pm 0.44$ \\
\hline Iron & $11.87 \pm 0.31$ & $8.77 \pm 0.74$ \\
\hline Chromium & $0.08 \pm 0.04$ & $0.11 \pm 0.03$ \\
\hline Cadmium & $2.37 \pm 0.03$ & $2.68 \pm 0.16$ \\
\hline Manganese & $10.78 \pm 0.30$ & $15.62 \pm 0.13$ \\
\hline Aluminum & $10.88 \pm 0.28$ & $10.57 \pm 0.12$ \\
\hline Potassium & $7.88 \pm 0.08$ & $8.63 \pm 0.15$ \\
\hline
\end{tabular}

Values are means of triplicates with standard deviation $(P \leq 0.5)$

\section{Discussions}

The result of heavy metal determination in cassava tubers grown around two major cement factories in Ogun state is as shown in Table 1. Metals evaluated for their concentrations were lead, copper, arsenic, zinc, iron, chromium, cadmium, manganese, aluminum and potassium. Human exposure to toxic heavy metals such as cadmium, iron, copper, zinc, lead, arsenic, chromium, potassium, aluminum and manganese is known to be responsible for many human health problems. Contaminated 
food is however a major source of such heavy metals to man. The concentration of lead in cassava tubers grown around the two cement factories are $0.09 \mathrm{mg} / \mathrm{kg}$ (Ibese) and $0.28 \mathrm{mg} / \mathrm{kg}$ (Ewekoro) respectively. Lead toxicity can cause development of auto-immunity in which a person's immune system attacks its own cells leading to diseases of kidney, nervous system and circulatory system [15]. According to literature, heavy metals have been found in cassava tubers and have a potential health hazards to man through the dietary pathway in Nigeria [16]. However, lead levels in both cassava tubers are within the maximum level of $0.2 \mathrm{mg} / \mathrm{kg}$ recommended by WHO/FAO (2013). $4.75 \mathrm{mg} / \mathrm{kg}$ of copper was obtained in cassava tubers from Ibese cement factory while $7.60 \mathrm{mg} / \mathrm{kg}$ was found in cassava tubers of Ewekoro cement factory. The copper levels in both cement factories were higher than the permissible level of $0.05-0.5 \mathrm{mg} / \mathrm{kg}$ recommended by WHO/FAO. Sensitivity to toxic effects of excess dietary copper is influenced by its chemical form and interaction with other dietary minerals. Higher levels can cause symptoms of acute toxicity, including nausea, abdominal discomfort (diarrhea), haemoglobinuria or haematuria, jaundice, hypotension, coma, and death [17]. Had recommended $0.1 \mathrm{mg} / \mathrm{kg}$ arsenic level in foods. The levels of arsenic which are $0.32 \mathrm{mg} / \mathrm{kg}$ and $0.36 \mathrm{mg} / \mathrm{kg}$ obtained in cassava tubers grown around the two cement factories were above FAO/WHO permissible level. High level of arsenic can cause death [18]. It was also reported that arsenic exceeding permissible limit $(0.1 \mathrm{mg} / \mathrm{kg}$ ) in food stuff could cause in the short term (nausea, vomiting, diarrhea, cough and headache) long term (cardiovascular diseases, diabetes and vascular diseases) human health effects [19].

The level of zinc in cassava samples from the two cement factories are $4.03 \mathrm{mg} / \mathrm{kg}$ and $5.00 \mathrm{mg} / \mathrm{kg}$ respectively. The concentrations of zinc in the samples were above the maximum level of $0.3-1 \mathrm{mg} / \mathrm{kg}$ recommended. [17]. In human, high levels of zinc can cause acute effects such as vomiting and gastrointestinal irritation (nausea, cramps, diarrhea). Impaired copper uptake in human has been noted following the chronic intake of zinc, hence, some effect of zinc therefore may be secondary to impaired copper utilization (ie anemia) [17]

Cadmium levels are $2.37 \mathrm{mg} / \mathrm{kg}$ and $2.68 \mathrm{mg} / \mathrm{kg}$. Higher level was found in cassava tubers obtained from Ewekoro cement factory while lower level was detected in cassava grown around Ibese cement factory. Cadmium pollution is as a result of its ease of contamination of foods [20]. Severe exposure of cadmium may result in pulmonary renal effect. The concentration of cadmium detected in cassava samples from the two locations exceeded the recommended limit of FAO/WHO (2011) which is $0.1 \mathrm{mg} / \mathrm{kg}$.

Iron is an essential trace element required by all forms of life. In man, it is required for the synthesis of hae protein as well as in many enzyme systems [17]. Maximum level recommended is $0.8 \mathrm{mg} / \mathrm{kg}$ iron in foods, therefore, $11.80 \mathrm{mg} / \mathrm{kg}$ and $8.77 \mathrm{mg} / \mathrm{kg}$ levels of iron obtained from cassava tubers grown around the two cement factories were well above the tolerable level. In human, acute toxicity of iron ingested can lead to siderosis (deposition of iron on the tissue) in liver, pancreas, adrenal, thyroid, pituitary and heart depending on the chemical form [17]

The concentrations of chromium in cassava tubers at Ibese (Dangote cement factoty) was $0.08 \mathrm{mg} / \mathrm{kg}$ while that of Ewekoro (Larfarge cement factory) was $0.11 \mathrm{mg} / \mathrm{kg}$. Both levels were below $2.30 \mathrm{mg} / \mathrm{kg}$ maximum recommended.[17] Aluminum toxicity can be traced to deposition in bone and central nervous systems, which is particularly increased in patients with reduced renal function. $10.88 \mathrm{mg} / \mathrm{kg}$ and $10.5 \mathrm{mg} / \mathrm{kg}$. Aluminum obtained from the cassava grown around the two major cement factories showed a serious increase in its level when compared with $1 \mathrm{mg} / \mathrm{kg}$ maximum limit stipulated [17]. Other metals, manganese and potassium were also above the permissible maximum limits recommended [17]

\section{CONCLUSION}

The results of analysis of heavy metals in cassava grown around cement factories in Ogun state showed that with the exception of chromium and potassium, all other heavy metals were above the permissible levels stipulated by FAO/WHO. Some heavy metals are non-biodegradable and their accumulation in the body can lead to various diseases and disorders. Efforts made by the relevant government agencies to curtail the indiscriminate discharge of industrial effluents containing these heavy metals should be put in place so that local communities around the cement factories are not put in danger. 


\section{ACKNOWLEDGEMENT}

The Author wishes to acknowledge the contribution of Elias Augusta Amaka in providing technical assistance in the course of this work.

\section{REFERENCES}

[1] Hawkes, J.S. (1997). Heavy metals. J. Chem. Educ. 74(11):1374

[2] Divrikli, V, Saracoghi, S, Soylak, M and Elci, L (2003). Determination of trace heavy metal content of green vegetable sample from kayseri-turkey by flame atomic absorption spectrometry. Ereserius Environmental Bulletin (FEB). 12: 1123-1125

[3] Dundar, M.S and Saglam, H.B (2004). Determination of cadmium in tea varieties and their infusions in comparison with 2 infusion processes. Trace Elem. Electrolyte. 21: 60-63

[4] Colak, H, Soylak, M and Turkoghu, O (2005). Determination of trace metal content of various herbal and fruit teas produced and marketed from Turkey. Trace Elem. Electrolyte 22: 192-195

[5] Oktem, F, Yavrucoghi, H, Turedi, A and Tunc, B (2005). The effect of nutritional habits on hematological parameters and trace element in children. Suleyman Demirel Univ. Tipo Fak Dev.12:6-10

[6] Ellen,G , Loon, J.W and Toolsmak, K (1990). Heavy metals in vegetables grown in the Netherlands and in domestic and imported fruit. Z. lebensm. Unters forsch. 190: 34-39

[7] Cieslinski, G, Van-Reesi, K.C.J, Hvary, P.M, Kozak, L.M, Rostad, H.P.W and Knolt, D.R (1996). Cadmium uptake and bioaccumulation in selected cultivars of durum wheat and flax as affected by soil type. Plant and soil. 182: 115-124

[8] FAO/WHO (2011). Food Standard Programme, codex Committee on Contaminated Foods. Fifth session, the Hague, Netherlands: 21-25

[9] IFAD (2001). International Fund for Agricultural Development 'Strategic Environmental Assessment: An assessment of the impact of cassava introduction and processing on the environment and biodiversity (vol5)'. Proceeding of the Validation Forum on the Global Cassava Development Strategic, Rome, 26-28 April 2000

[10] Bilen, S (2010). Effect of cement dust pollution in microbial properties and enzyme activities in cultivated and no till soil: African Journal of Microbiology Research, Vol 4 (22), 2418-2425

[11] Demir, T.A, Isikli, B, Urer.S.M, Berber,A ,Aker, T, Canbek, M and Kalyoncu, C (2005). Nickel exposure and its effects. Bio-metal. 18: 13-17

[12] Bayhan, Y.K and Ozbay, O (1992). Cadmium exposure from the chemical dust emission in field in a rural residence chemosphere IN: Iskili et al 2006. 63: 1546-1552

[13] Adriano, D.C, (2001). Trade elements in terrestrial environments: biogeochemistry bioavailability and risk of metal. $2^{\text {nd }}$ edn: In: Zhnang et al.,(2009). Health risk from heavy metals via consumption of food crops in the vicinity of Dabaasthan mine, South China: Science of the Total Environment. 1551-1561

[14] Adedeji, A, and Ajibade I.T. (2005). Quality of well water in ede area. South Western Nigeria. J. human. Ecol. 17: 223-228.

[15] Casarett and Doull. (1996). Heavy metals and Health. World Resources Institute. Washington, USA

[16] Obiajunwa, E.L. Pelemo, D.A, Owolabi, S.A, Fasai, M.K, John-Fatokun, F.O (2002). Metal Pollutant of soil and sediments around a crude oil Production Terminal using EDXRF. Nucl. Instr Methods Phys B. 194, 61-64.

[17] Ogwuegbu, M.O.C and Ijeoma, M.A. (2003). Effect of certain heavy metals on the population due to mineral Exploitation in: International Conference on Scientific and Environmental issues in the Population, Environment and Sustainable Development in Nigeria. University of AdoEkiti, Ekiti State, Nigeria:8-10

[18] Col, M, Col, C, Soran, A, Sayli, B.S and Ozturk, S (1999): Arsenic-related Bowen's Disease. Palmar Keratosis and Skin Cancer. Enviro. Health Perspect. 107: 687-689.

[19] Galadima, A and Garba,Z.N.(2012). Heavy metals pollution in Nigeria and consequences. Elizir pollution 45: 7a17-7922 